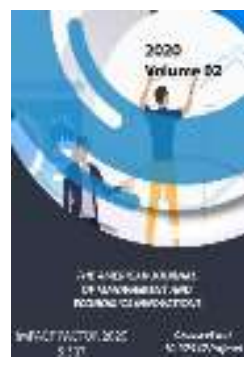

\title{
Statistical Forecasts Of The Economic Potential Of Industry Of The Surkhandarya Region And The Prospects Of Its Further Development
}

\author{
Azamat Abdukarimovich Qosimov \\ PhD Student, Termez State University, Republic Of Uzbekistan
}

\begin{abstract}
Journal Website: http://usajournalshub.c om/index,php/tajmei

Copyright: Original content from this work may be used under the terms of the creative commons attributes 4.0 licence.
\end{abstract}

\section{ABSTRACT}

This article examines the economic potential of the industrial sector of Surkhandarya region and analyzes it using statistical, economic-mathematical and econometric methods. Also, the mediumterm forecast values of indicators representing the economic potential of the regional industry (20202025) were developed and the directions for its further development were highlighted.

\section{KEYWORDS}

Industry, modernization, investment, export, labor potential, economic potential, model.

\section{INTRODUCTION}

In order to ensure the efficient use of available natural and labor resources, socio-economic development of the region, sustainable economic growth, large-scale reforms are being carried out in Surkhandarya region to further increase the regional industrial potential, ultimately provide employment and welfare. In particular, by the Decree of the President of the Republic of Uzbekistan dated March 29, 2018 "On measures to establish small industrial zones in Surkhandarya region", 9 unused state-owned facilities and small industrial zones were established in the region. Of course, this is important as it will create new jobs in the region's industrial production, increase employment and welfare.

As a result of practical work carried out in recent years to modernize and diversify industrial enterprises in the region and the creation of new industrial enterprises, in 
particular, in 2019 the volume of industrial output in the region amounted to 4402.8 billion. soums, which is $16.0 \%$ of the gross regional product. Compared to 2018, the volume of industrial production increased by 109.3\%. However, these figures are 3-4 times lower than the national level. Also, although the region exports electricity, textiles and other industrial products, it accounts for only 1$2 \%$ of the region's exports (2019, \$240.6 million).

However, due to the natural location and fertile lands of the region, it has a large base of cheap, high-quality agricultural products. This will allow the supply of industrially processed agricultural products to domestic and foreign markets. However, due to the geographical location of the region, inconvenient transport infrastructure, the logistics costs associated with the transportation of goods are high.

Therefore, statistical, economic-mathematical, econometric analysis and forecasting of indicators such as the volume of industrial production, the volume of investments in industrial sectors, labor productivity in industry, as well as the development of promising strategies to increase the economic efficiency of regional industry is one of the most pressing issues of the day.

\section{LITERATURE REVIEW}

In the early twentieth century, many economists noted that industrialization was a key direction of economic development (Lavopa and Szirmai, 2012). That is, industry began to be seen as a key mechanism of economic growth, economic development, and social development.

Sustainable industrial development has always been of great economic importance to countries. Because development is in many ways directly related to the development of regional industry, the effective use of the potential of the region's industry in the implementation of tasks such as ensuring regional stability and economic growth, deep structural changes in the regions and achieving the intended regional forecast parameters (Mahmudov and et al., 2018).

An important feature of the industrial complex is that in all its branches are created means of labor and consumer goods, a large part of national income, scientific and technological progress is achieved (Botirova, 2019).

In general, the production potential of the region means the ability to ensure long-term sustainable development through the efficient and rational use of available resources and the formation, identification and satisfaction of consumer demand for industrial products in the interaction with the external environment (Mahmudov, 2019).

It is important to analyze the volume of industrial output in the regions by comparing interregional and regional indicators with the country's indicators, analyzing the dynamics of industrial output per capita and setting priorities and growth points in the regions (Salimov, 2018).

Industrial development will depend on a number of opportunities, geographical and economic factors (Artikov, 2009). Therefore, statistical analysis of the economic potential of this sector has always aroused great practical interest (Glushko et al., 2017).

\section{RESEARCH METHODOLOGY}

Economic, statistical, comparative analysis, economic-mathematical, econometric methods were used in the research process. Also used the published scientific works of local and foreign scientists on this topic, as well as official statistics of the Statistics Committee of the Republic of Uzbekistan, the Statistics Department of Surkhandarya region and the Main Department of Employment. 


\section{ANALYSIS AND RESULTS}

In the context of rapid economic change, there is no practice of forming targets (indicators) based on socio-economic development of Surkhandarya region, as well as identifying new sources of economic growth, taking into account existing internal and external factors and strategic priorities of reforms. In addition, the effective use of research in the organization and development of productive forces to ensure sustainable economic growth through the development of regional economies, including industrial capacity, and the development of socio-economic development prospects based on statistical analysis and forecasting methods are not satisfactory.

In recent years, economists (Korobeynikov et al., 2003) have been conducting research in this area, emphasizing that labor productivity is another factor in the development of the industrial sector.

This study also showed that one of the important factors in the development of regional industries is the productivity of labor resources. Therefore, today in the system of economic and social relations, labor resources are considered as the main force. Labor productivity in industry is determined as follows.

$$
M U=\sum \boldsymbol{Q} / \sum \boldsymbol{L}
$$

Here:

$\boldsymbol{M U}$ - labor productivity in industry;

$\boldsymbol{Q}$ - volume of industrial production; the industry.

$\boldsymbol{L}$ - the number of people employed in

Today, more than 71.1 thousand people work in the industrial sector of the region. Labor productivity in the sector, ie an average of 56.9 million people per person employed in the regional industrial enterprises. UZS corresponds to industrial products (Figure 1).

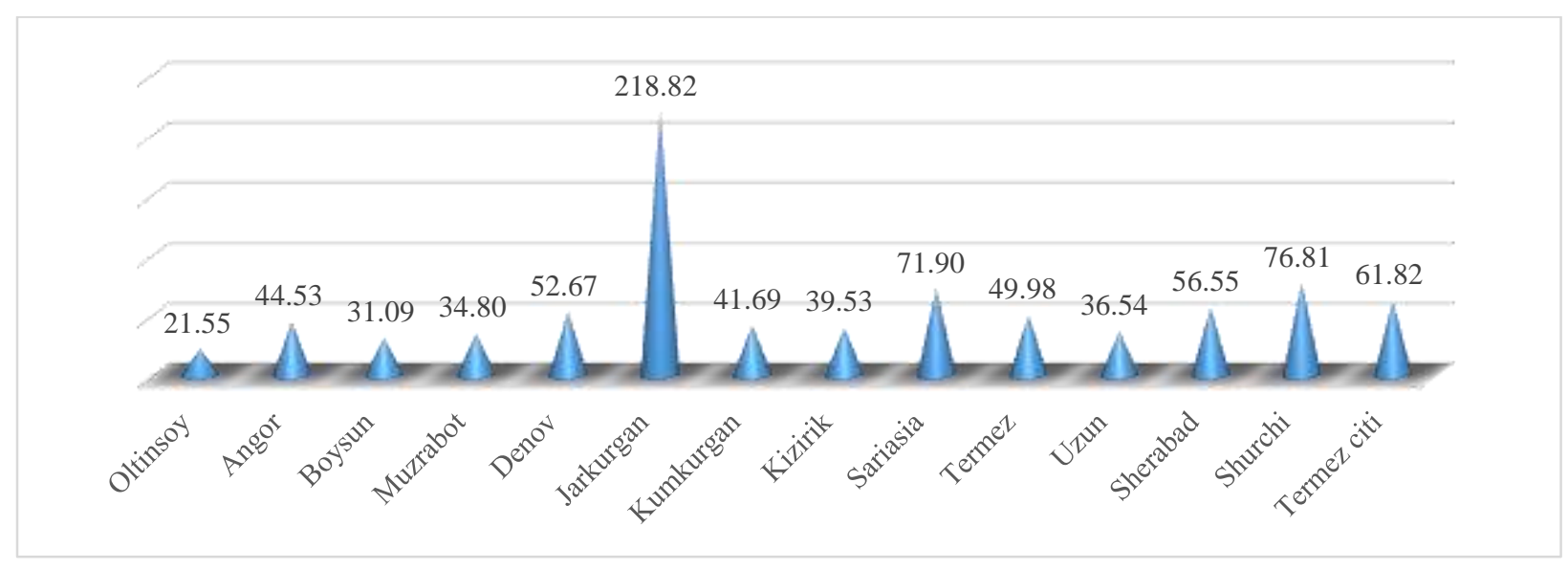

Figure 1. Labor productivity in the industry of Surkhandarya region ${ }^{1}$ (million soums / person)

\footnotetext{
${ }^{1}$ Data of Surkhandarya region Statistics Department and General Employment Department.
} 
According to the analysis, the regions with the highest labor productivity in industry are Jarkurgan district (218.82 million soums), Shurchi district (76.81 million soums), Sariosiya district (71.90 million soums) and Termez city (61, Oltinsoy (21.55 million soums), Boysun (31.09 million soums), Muzrabot (34.80 million soums), Uzun ( 36.54 million soums). ) and Qizirik (39.53 million soums) districts. Of course, it depends on the specialization, development and a number of other aspects of the enterprises in these areas by industry.

In general, one of the main directions of highincome employment of the population of the region is the development of regional industries. In turn, this requires investment (capital, technology, innovative projects, etc.).

Foreign experience shows that countries with developed market economies have long implemented different strategies to support national industrial complexes. At the same time, the state encouraged industrial enterprises and organized the implementation of innovative structural changes in various areas in a centralized manner. As a result, favorable conditions have been created for the inflow of investments into promising sectors and the attraction of foreign business investors (Topoleva, 2018).

Investments are an integral part of aggregate demand and, if used effectively, have an effective effect on capital growth and the productive capacity of the economy (as a longterm supply).

In general, investments are financed by current savings or borrowed funds. According to the analysis, a total of 12,232.4 billion soums will be invested in fixed assets in Surkhandarya region in 2019. UZS, of which centralized investments by sources of financing amounted to 1397.5 bln. soums (including 662.4 billion soums of budget funds, 134.0 billion soums of state trust funds, 601.1 billion soums of loans guaranteed by the Republic of Uzbekistan) and decentralized investments of $10,834.9$ billion soums. soums (including 1338.3 billion soums of enterprise funds, 1002.0 billion soums of population funds, 6956.5 billion soums of foreign direct investment and loans, 1538.1 billion soums of loans of commercial banks and other loans) $\mathrm{did}^{2}$.

Statistical analysis shows that in recent years, the volume of disbursed investments in the region has a high growth trend. In particular, in 2016, 2005.2 bln. soums (growth rate 111.2\%), in $2017-3551.0$ bln. soums (152.1\%), in 2018 - 7240.6 billion soums. soums (149.5\%) and in 2019 12232.4 bln. soums (148.8\%) (Table 1).

\footnotetext{
${ }^{2}$ Data of Surkhandarya region statistics department.
} 
The American Journal of Management and Economics Innovations

Table 1

The volume of investments disbursed in Surkhandarya region in 2010-2019 (billion in soums)

\begin{tabular}{|c|c|c|c|c|c|c|c|c|c|c|c|}
\hline $\mathbf{N}=$ & $\begin{array}{c}\text { Name of } \\
\text { the region }\end{array}$ & $\mathbf{2 0 1 0}$ & $\mathbf{2 0 1 1}$ & $\mathbf{2 0 1 2}$ & $\mathbf{2 0 1 3}$ & $\mathbf{2 0 1 4}$ & $\mathbf{2 0 1 5}$ & $\mathbf{2 0 1 6}$ & $\mathbf{2 0 1 7}$ & $\mathbf{2 0 1 8}$ & $\mathbf{2 0 1 9}$ \\
\hline 1 & Oltinsoy & 31,9 & 36,9 & 43,6 & 54,7 & 63,7 & 70,4 & 81,0 & 122,4 & 245,7 & 259,5 \\
\hline 2 & Angor & 23,9 & 24,3 & 29,0 & 39,1 & 48,1 & 61,0 & 80,4 & 133,1 & 248,8 & 325,9 \\
\hline 3 & Boysun & 96,1 & 68,4 & 82,4 & 109,1 & 136,9 & 156,6 & 199,7 & 266,4 & 535,9 & 4998,2 \\
\hline 4 & Muzrabot & 20,4 & 26,4 & 33,7 & 44,4 & 51,9 & 59,0 & 70,0 & 108,4 & 214,9 & 346,2 \\
\hline 5 & Denov & 51,4 & 57,6 & 64,4 & 85,6 & 101,3 & 119,4 & 151,1 & 210,5 & 396,2 & 598,6 \\
\hline 6 & Jarkurgan & 56,8 & 57,9 & 71,2 & 111,7 & 134,6 & 157,2 & 194,0 & 266,1 & 622,3 & 681,1 \\
\hline 7 & Kumkurgan & 43,5 & 50,2 & 62,1 & 78,6 & 93,3 & 109,5 & 126,7 & 232,2 & 300,3 & 319,0 \\
\hline 8 & Kizirik & 41,8 & 49,3 & 57,5 & 73,1 & 84,8 & 97,3 & 115,3 & 160,0 & 391,6 & 591,9 \\
\hline 9 & Sariasia & 26,2 & 90,2 & 106,6 & 141,6 & 171,8 & 196,4 & 235,1 & 359,8 & 826,7 & 877,3 \\
\hline 10 & Termez & 38,7 & 45,8 & 55,1 & 96,8 & 115,3 & 145,9 & 187,9 & 272,2 & 495,7 & 688,3 \\
\hline 11 & Uzun & 22,8 & 23,3 & 28,9 & 41,7 & 50,0 & 56,4 & 72,2 & 106,7 & 143,7 & 240,4 \\
\hline 12 & Sherabad & 27,7 & 35,6 & 42,8 & 60,4 & 75,4 & 88,0 & 105,9 & 483,7 & 1430,4 & 525,2 \\
\hline 13 & Shurchi & 26,8 & 27,8 & 30,8 & 42,7 & 50,3 & 57,8 & 65,9 & 117,8 & 201,4 & 286,7 \\
\hline 14 & Termez citi & 61,8 & 88,3 & 99,9 & 168,1 & 199,8 & 258,6 & 310,1 & 711,6 & 1186,9 & 1494,1 \\
\hline
\end{tabular}

According to the analysis, in 2010-2019, the highest amount of total investments in fixed assets in the regions fell to the share of 5 districts, ie 665.0 billion soums in Boysun. soums, in the city of Termez -457.9 bln. soums, 287.5 bln. soums in Sherabad. soums, in Jarqurghon - 235.3 bln. soums and 214.2 bln. soums in Termez district. sum In contrast, the lowest figures were in Angor at 101.4 billion. soums, in Oltinsoy bln. soums, in Muzrabat bln. soums, 90.8 bln. soums in Shurchi. soums and 78.6 bln. soums in Uzunda. soums were returned. It can be said that the high rate of investment development in the regions is mainly in 2017-2019. In particular, compared to 2010, in 2015 there was an increase in investment in Sariosiya (7.5 times), Termez city (4.2 times), Termez (3.8 times) and Sherabad (3.2 times) districts. while Boysun (52.0 times), Sariosiyo (33.5 times), Termez (24.2 times), Sherabad (19.0 times), Termez (17.8 times), Muzrabat (17.0 times), An increase was observed in Qizirik (14.2 times) and Angor (13.6 times) districts ${ }^{4}$.

As a positive result of these investments, industrial enterprises with foreign investment have been established in some regions of the region, and today these enterprises are engaged in the production of industrial products (Table 2 ).

\footnotetext{
${ }^{3}$ Data of Surkhandarya region statistics department.

${ }^{4}$ Author's calculations based on the data of the Statistics Department of Surkhandarya region.
} 
Table 2

Dynamics of production volumes of industrial enterprises with foreign investment in the Surkhandarya region ${ }^{5}$ ( $\mathrm{mln}$. in soums)

\begin{tabular}{|c|c|c|c|c|c|c|c|}
\hline № & $\begin{array}{c}\text { Name of the } \\
\text { district }\end{array}$ & 2014 & 2015 & 2016 & 2017 & 2018 & 2019 \\
\hline 1 & Oltinsoy & 353,9 & 290,2 & 2732,1 & 32391,3 & 19698,4 & 25616,8 \\
\hline 2 & Denov & 157,3 & 115,0 & - & - & 121,3 & 91,6 \\
\hline 3 & Jarkurgan & 200806,1 & 232795,8 & 235464,2 & 302584,0 & 443709,0 & 561161,9 \\
\hline 4 & Kumkurgan & 4047,6 & 4699,0 & 6003,2 & 6905,8 & 10224,1 & 15345,4 \\
\hline 5 & Sariasia & 887,0 & 831,9 & 1465,3 & 2265,0 & 3094,6 & 4687,4 \\
\hline 6 & Termez & 43,5 & & 6,0 & & 574,8 & 334,6 \\
\hline 7 & Uzun & - & - & - & - & - & 38,9 \\
\hline 8 & Sherabad & 8333,2 & 9395,9 & 11945,9 & 12802,6 & 37116,8 & 24407,4 \\
\hline 9 & Shurchi & - & 750,0 & 1135,3 & 976,8 & 2011,6 & 2215,8 \\
\hline 10 & Termez citi & 23977,8 & 16667,6 & 20166,0 & 50171,7 & 49337,2 & 148140,5 \\
\hline & Total & 238606,3 & 265545,5 & 278917,8 & 408097,2 & 565887,8 & 782040,4 \\
\hline
\end{tabular}

According to Table 2, in 2019 in Surkhandarya region by joint ventures with foreign investment amounted to 782.1 billion soums. UZS, which is 3.3 times more than in 2014 . However, this does not mean that the investments being made in the oasis are being used effectively. This is evidenced by the analysis of the technical structure of

\footnotetext{
${ }^{5}$ Data of Surkhandarya region statistics department.
}

investments, ie the structure of the areas and directions in which investments are directed. The analysis shows that in $2019,61.8 \%$ of the total investment in the economy of Surkhandarya region was spent on housing construction and installation, $28.7 \%$ on the purchase of technology and the remaining 9.5\% on other expenses. At the national level, this figure was 62.3 percent, 34.4 percent, and 3.3 percent, respectively (Figure 2 ). 


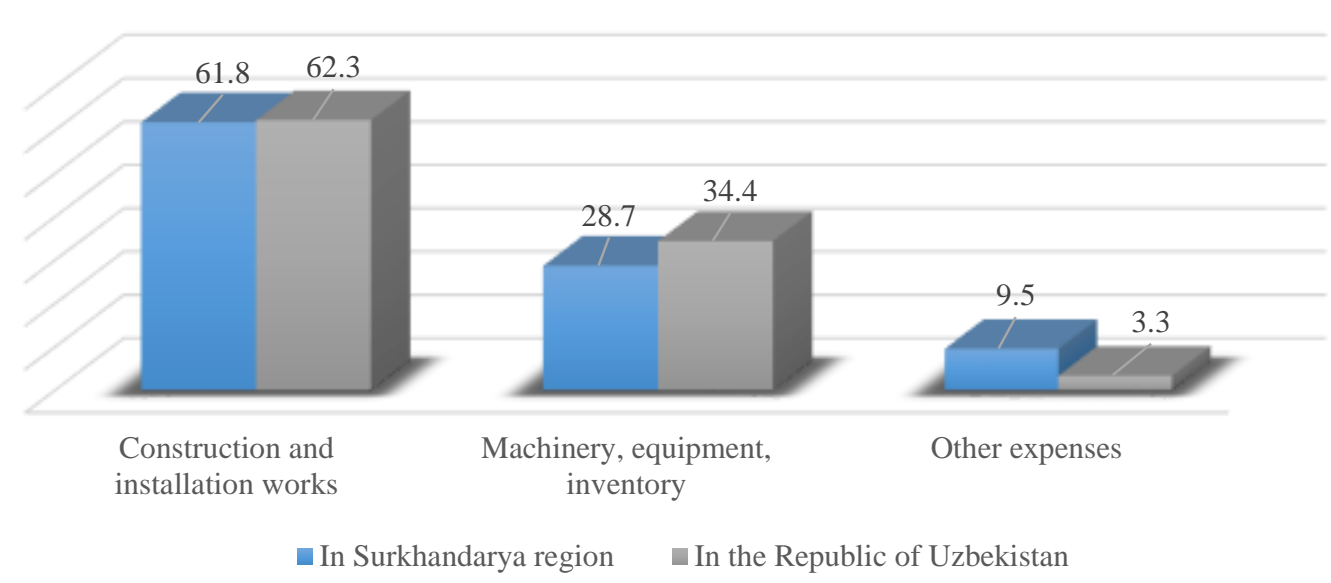

Figure 2. Technological structure of investments ${ }^{6}$, percent

According to the results of statistical analysis of investments by type of economic activity, $38.0 \%$ of total investments in the regional economy are in industry, including $24.4 \%$ in mining, $13.6 \%$ in manufacturing and $3.6 \%$ in agriculture. and 58.4 percent in other areas. At the national level, this process accounted for $11.4 \%$ in the extractive industry, $22.0 \%$ in manufacturing, $3.3 \%$ in agriculture, forestry and fisheries, and $63.2 \%$ in other sectors.

In conclusion, the lack of attention to the manufacturing industry in Surkhandarya region or the existence of a number of problems in its development, including demand for industrial products and low incomes and labor productivity, as well as high transportation costs in the sale of products.

The experience of foreign countries in the use of investments was also studied during the study of the above processes. In particular,
$48.0 \%$ of the technological structure of investments in Kazakhstan (real estate) fell to the construction sector, $30.5 \%$ to the transport and storage sector, $6.1 \%$ to industry and $15.4 \%$ to other sectors ${ }^{7}$ (Table 3 ).

In Russia, this process is $56.0 \%$ in construction (including $43.3 \%$ of economic facilities and $12.7 \%$ of housing), $34.6 \%$ in the acquisition of technology, $3.1 \%$ in the formation of intellectual property and $6.3 \%$ in other sectors ${ }^{8}$ (Table 3 ).

The situation in European countries in this direction can be explained by the following. The European Fund for Strategic Investment (EFSI) was established (balance sheet 33.5 billion euros), with $28.5 \%$ of the fund's funding for small business, $22.0 \%$ for research and development, $22.0 \%$ for the energy sector, $11.0 \%$ digital networks, 9.0 percent for transport, 4.0 percent for social infrastructure and 4.0 percent for environment and natural resources $^{9}$ (Table 3 ).

\footnotetext{
${ }^{6}$ Compiled by the author on the basis of data of the State Statistics Committee of the Republic of Uzbekistan.

${ }^{7}$ http://astana.gov.kz/ru/page/investicii_v_osnovnoy_kapital

8 https://expert.ru/expert/2019/38/oligarh-uvidel-perspektivu/

9 https://ru.euronews.com/2018/07/10/rb-12-investment-plan-efsi-master
} 


\section{Table 3}

\section{Investments in foreign countries technological structure ${ }^{10}$ percent}

\begin{tabular}{|c|c|c|c|c|c|c|c|c|}
\hline $\begin{array}{l}\text { Areas of } \\
\text { investment } \\
\text { Country } \\
\text { names }\end{array}$ & 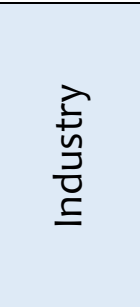 & 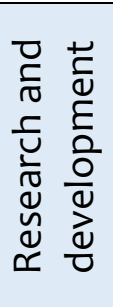 & 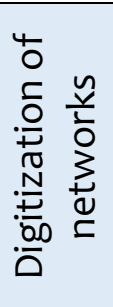 & 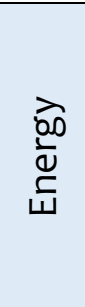 & 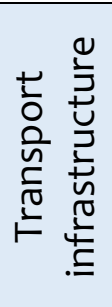 & 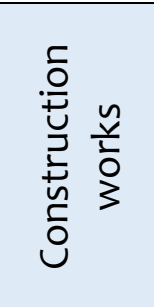 & 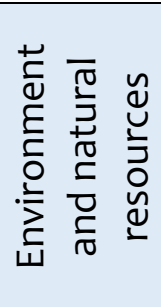 & $\frac{n}{\frac{n}{2}}$ \\
\hline Europe* & 28,5 & 22,0 & 11,0 & 21,5 & 9,0 & $4,0 * * *$ & 4,0 & - \\
\hline Russia & $34,6 * *$ & 3,1 & - & - & & $\begin{array}{c}56,0 * * * \\
*\end{array}$ & - & 6,3 \\
\hline Kazakhstan & 6,1 & - & - & - & 30,5 & $\begin{array}{c}48,0 * * * \\
* *\end{array}$ & - & 15,4 \\
\hline Uzbekistan & $34,4^{* *}$ & - & - & - & - & 62,3 & - & 3,3 \\
\hline Surkhandarya & $28,7^{* *}$ & - & - & - & - & 61,8 & - & 9,5 \\
\hline
\end{tabular}

Note: * The European Fund for Strategic Investment (EFSI) was established, with a fund balance of $\$ 33.5$ billion. euro;

** mainly for technology acquisition;

*** for the development of social infrastructure;

$* * * * 43.3 \%$ for the construction of economic facilities and $12.7 \%$ for residential construction;

***** mainly spent on building large real estate.

In our opinion, most of the investments in our country, especially in Surkhandarya region, are spent not on industry, but on other areas. However, the focus on the organization or development of the production process, as well as the development of scientific progress (training of qualified personnel, development of scientific research, etc.) is, unfortunately, weak. In particular, the basis of localization of

production is scientific and technological progress.

It is no secret that at the same time around the world there is a process of economic development based on the introduction of high-tech innovative developments in industries (Grebenkin, Botkin, 2017).

Sectoral and regional priorities need to be set to attract and use investment effectively. First of all, an in-depth analysis of the existing regional features of economic development, including industry, agriculture, infrastructure, social sphere, living standards, transport and communications, socio-economic stratification of the region and its causes, and the priorities of socio-economic development. should be addressed (Eremeeva, Plisetskiy, 2013).

It is known that the volume and internal structure of investments determine economic growth, labor productivity, the level of

\footnotetext{
${ }^{10}$ A comparative analysis was performed by the author based on official statistics.
} 
elements of economic development and the rate of development (Vahobov et al., 2010).

The relationship between investment and economic growth is based on the one-factor economic growth model of Harrod-Domar (Harrod, 1939), (Domar, 1946):

$$
G C=S \text { or } G=S / C
$$

Here:

$G$ - additional growth rate of GRP;

$C$ - investment efficiency ratio (additional growth of investment volume / GRP);

\section{Table 4}

The main economic indicators and growth rates of Surkhandarya region ${ }^{11}$

\begin{tabular}{|c|c|c|c|c|c|}
\hline Years & $\begin{array}{c}\text { GRP volume, } \\
\text { (billion } \\
\text { soums) }\end{array}$ & $\begin{array}{c}\text { Investment } \\
\text { volume, } \\
\text { (billion soums) }\end{array}$ & $\begin{array}{c}\text { Share of } \\
\text { investments } \\
\text { in GRP, (\%) }\end{array}$ & $\begin{array}{c}\text { Investment } \\
\text { efficiency (billion } \\
\text { soums /\%) }\end{array}$ & $\begin{array}{c}\text { Additional } \\
\text { growth rate of } \\
\text { GRP }\end{array}$ \\
\hline 2016 & 11546,0 & 2005,2 & 17,4 & 345,7 & 0,05 \\
\hline 2017 & 13702,2 & 3551,0 & 25,9 & 1014,6 & 0,03 \\
\hline 2018 & 17061,9 & 7240,6 & 42,4 & 1540,6 & 0,03 \\
\hline 2019 & 22349,3 & 12232,4 & 54,7 & 1941,7 & 0,03 \\
\hline
\end{tabular}

According to the analysis, during 2016-2019, the average additional growth rate of GRP in relation to investment in the region was $0.4 \%$.

Also, the analysis of the dynamics of some indicators representing the potential of industrial sectors of Surkhandarya region showed the following trends (Figure 3).

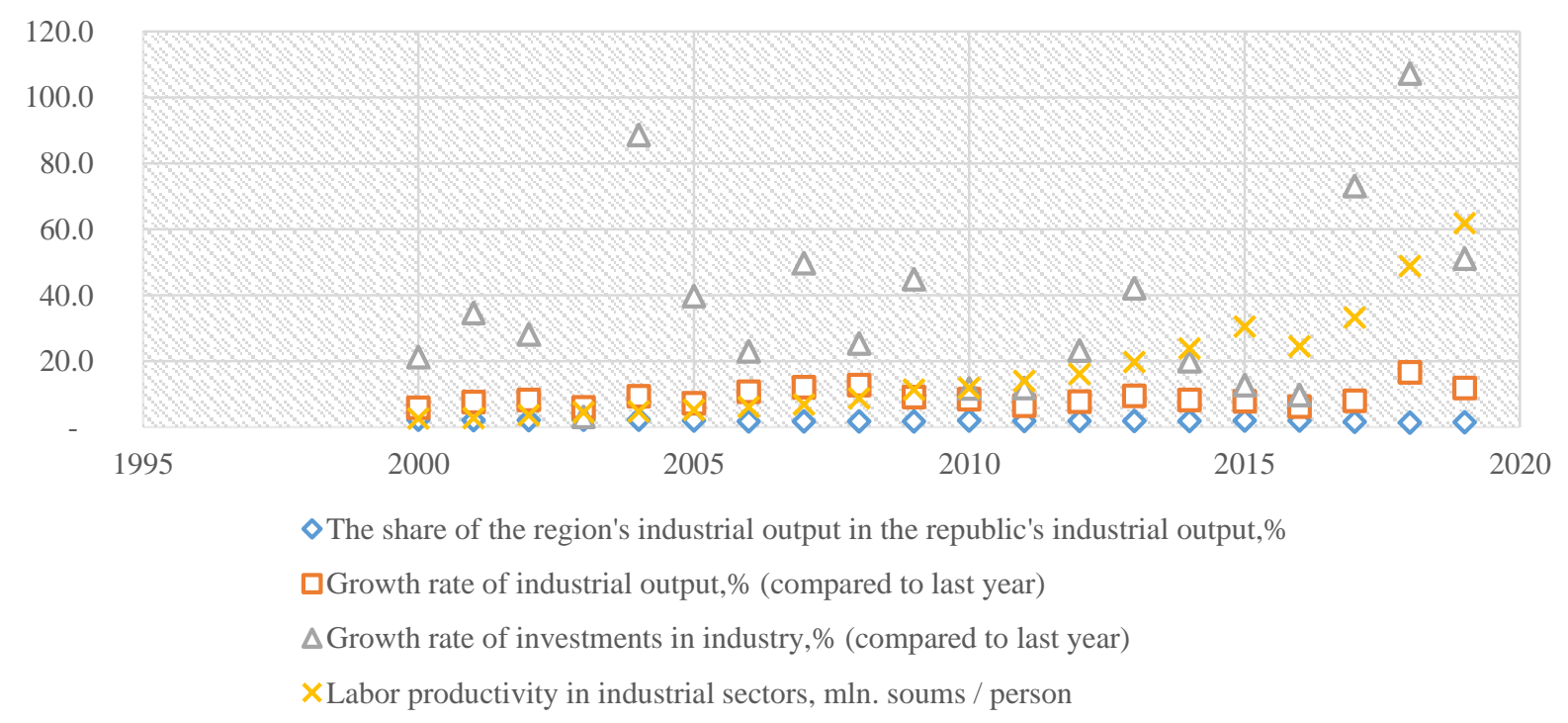

Figure 3. Dynamics of indicators representing the economic potential of industrial sectors of Surkhandarya region ${ }^{12}$

\footnotetext{
${ }^{11}$ Data of Surkhandarya region statistics department and author's calculations.

${ }^{12}$ Compiled by the author on the basis of data from the Surkhandarya regional statistics department.
} 
As shown in Figure 3, from 2000 to 2019, the regional industrial output accounted for an average of $1.9 \%$ of the republic's industrial output, the average growth rate of industrial production was $8.9 \%$, the average growth rate of investment in industry was $35.3 \%$, and Labor productivity in the industries averaged 14.7 million per capita. The upward trend in the amount of UZS was reversed.

According to the results of the study, today the potential of the regional industry is much lower than the national average and one of the priorities is to ensure socio-economic development based on increasing the level of industrialization of the regional economy through the rational use of unused resources and opportunities. This requires the development of regional industry development strategies and analysis of the dynamics of forecast indicators of its development potential.

Of course, when forecasting dynamic series, it is necessary to take into account the changes in the data over many years. In particular, by increasing the importance of the trend of change in recent years, it is necessary to reduce the importance of the trend of change in the first years of the dynamic range (Shodiev et al., 2007).

Indeed, time is the main and only developmental factor in a dynamic task. It is based on the analysis of time series that represent changes in projected indicators over time (Djumanova, 2012). For example, the volume of industrial production, investment flows, changes in labor productivity over time are analyzed.

The dynamic function of forecasting interprets the one-way change in the observed indicators by dividing the developmental evolution of the forecasting process. In this case, the prediction of changes in the performance of the object in the coming period is formed by retrospective practice of its development.

Functions such as linear, hierarchical, exponential are often used in forecasting socio-economic processes:

$$
\begin{array}{r}
y_{t}=a_{0}+a_{1} t \\
(3) \\
y_{t}=a_{0}+a_{1} t+a_{2} t^{2} \\
y_{t}=a_{0} e^{a_{1} t}
\end{array}
$$

here: $y_{t}$ - expected forecast value, $t$ time factor, $e=2,718$ - natural logarithm basis.

Using the data of the Surkhandarya regional statistics department, it is necessary to create comparative trend models to classify the trends of forecast values of indicators representing the potential of the regional industries (Table 5). 
The American Journal of Management and Economics Innovations

\section{Table 5}

Comparative trend models on the indicators determining the economic potential of the industrial sector of Surkhandarya region ${ }^{13}$

\begin{tabular}{|c|c|c|c|c|}
\hline № & Indicators & $\begin{array}{c}\text { Unit of } \\
\text { measurement }\end{array}$ & Model name & Model \\
\hline \multirow{3}{*}{1} & \multirow{3}{*}{$\begin{array}{l}\text { Volume of } \\
\text { industrial } \\
\text { products }\end{array}$} & \multirow{3}{*}{ billion sum } & linear & $y_{t}=120,46+279,62 t$ \\
\hline & & & dvadratic & $y_{t}=692,48-32,395 t+31,201 t^{2}$ \\
\hline & & & exponential & $y_{t}=517,47 e^{0,1902 t}$ \\
\hline \multirow{3}{*}{2} & \multirow{3}{*}{$\begin{array}{c}\text { The volume of } \\
\text { investment in } \\
\text { industry }\end{array}$} & \multirow{3}{*}{ billion sum } & linear & $y_{t}=-274,12+197,45 t$ \\
\hline & & & dvadratic & $y_{t}=624,64-292,78 t+49,024 t^{2}$ \\
\hline & & & exponential & $y_{t}=145,96 e^{0,2614 t}$ \\
\hline \multirow{3}{*}{3} & \multirow{3}{*}{$\begin{array}{c}\text { Labor } \\
\text { productivity in } \\
\text { industry }\end{array}$} & \multirow{3}{*}{$\begin{array}{l}\text { mln. sum / } \\
\text { person }\end{array}$} & linear & $y_{t}=5,3407+3,8822 t$ \\
\hline & & & dvadratic & $y_{t}=12,736-0,1513 t+0,4034 t^{2}$ \\
\hline & & & exponential & $y_{t}=10,228 e^{0,1586 t}$ \\
\hline
\end{tabular}

Approximation error of structured models $(\bar{A})$, fisher criteria $(F)$, Student criteria $(t)$, Darbin-Watson criterion $(D W)$ checked using, standard error $\left(S_{y}\right)$ and determination coefficient $\left(R^{2}\right)$ identified (Table 6).

\section{Table 6}

The results of the evaluation of trend models based on indicators that determine the economic potential of the industrial sector of Surkhandarya region ${ }^{14}$

\begin{tabular}{|c|c|c|c|c|c|c|c|}
\hline № & Model & $\bar{A}$ & $F$ & $t$ & $D W$ & $S_{y}$ & $R^{2}$ \\
\hline \multirow{3}{*}{1} & $y_{t}=120,46+279,62 t$ & 14,6 & 45,1 & 2,$365 ; 0,5146$ & 1,55 & 322,55 & 0,866 \\
\hline & $\begin{aligned} y_{t}=692,48- & 32,395 t \\
& +31,201 t^{2}\end{aligned}$ & 10,2 & 34,9 & $\begin{array}{c}2,038 ; 0,2083 \\
2,0502\end{array}$ & 1,96 & 267,26 & 0,921 \\
\hline & $y_{t}=517,47 e^{0,1902 t}$ & 1,04 & 151,4 & 12,$3035 ; 71,855$ & 2,15 & 0,1197 & 0,956 \\
\hline \multirow{3}{*}{2} & $y_{t}=-274,12+197,45 t$ & 46,8 & 14,01 & 3,$7429 ; 0,9235$ & 1,02 & 408,65 & 0,667 \\
\hline & $\begin{aligned} y_{t}=624,64- & 292,78 t \\
+ & 49,024 t^{2}\end{aligned}$ & 31,9 & 21,55 & $\begin{array}{c}1,8365 ; 1,8748 \\
3,219\end{array}$ & 1,41 & 267,29 & 0,878 \\
\hline & $y_{t}=145,96 e^{0,2614 t}$ & 2,14 & 81,85 & 9,$0469 ; 30,6461$ & 1,11 & 0,2238 & 0,921 \\
\hline \multirow{3}{*}{3} & $y_{t}=5,3407+3,8822 t$ & 12,1 & 39,43 & 6,$2789 ; 1,5433$ & 1,69 & 4,7865 & 0,849 \\
\hline & $\begin{array}{r}y_{t}=12,736-0,1513 t \\
+0,4034 t^{2}\end{array}$ & 9,87 & 25,89 & $\begin{array}{c}2,335 ; 0,0582 \\
1,6468\end{array}$ & 1,96 & 4,2906 & 0,896 \\
\hline & $y_{t}=10,228 e^{0,1586 t}$ & 2,36 & 99,34 & 9,$9668 ; 26,0192$ & 2,12 & 0,1231 & 0,934 \\
\hline
\end{tabular}

\footnotetext{
${ }^{13}$ Developed by the author.

${ }^{14}$ Author's calculations using model verification criteria.
} 
According to the results of the analysis obtained (Table 6), additional alignment of the values of the indicators is required because the approximation error of the constructed linear and quadratic trend equations is greater than 5 percent. It was also found that while the values of the model parameters on the $\mathrm{F}$ and DWcriteria were satisfactory, they were statistically insignificant on the t-criterion. In addition, the standard error was greater than 1 and the determination coefficient showed relatively low values.
However, it was found that the exponential trend equations have an approximation error of less than $5 \%$, satisfy the model parameters on the $\mathrm{F}$ and DW-criteria, are significant on the $\mathrm{t}$-criterion, and have a standard error of less than 1 and a determination coefficient of more than $92.0 \%$. Based on this, forecast values of indicators representing the economic potential of industrial sectors of Surkhandarya region were developed (Table 7).

Table 7

Forecast values of indicators representing the economic potential of the industrial sector of Surkhandarya region in 2020-2025

\begin{tabular}{|c|c|c|c|c|c|c|c|}
\hline № & Indicators & $\mathbf{2 0 2 0}$ & $\mathbf{2 0 2 1}$ & $\mathbf{2 0 2 2}$ & $\mathbf{2 0 2 3}$ & $\mathbf{2 0 2 4}$ & $\mathbf{2 0 2 5}$ \\
\hline 1 & $\begin{array}{c}\text { Volume of industrial } \\
\text { production, bln. sum }\end{array}$ & 4792,0 & 5070,1 & 6132,1 & 7416,6 & 8970,1 & 10849,1 \\
\hline 2 & $\begin{array}{c}\text { The volume of investments in } \\
\text { industry, bln. sum }\end{array}$ & 2587,5 & 3360,4 & 4364,2 & 5667,8 & 7360,8 & 9559,6 \\
\hline 3 & $\begin{array}{c}\text { Labor productivity in industry, } \\
\text { mln. sum / person }\end{array}$ & 58,5 & 68,6 & 80,4 & 94,2 & 110,4 & 129,3 \\
\hline
\end{tabular}

According to the forecast, in 2025 the volume of industrial production in Surkhandarya region will increase by 3.4 times compared to the current period, the volume of investments in industry will increase by 4.1 times and labor productivity in industry will increase by 2.6 times.

\section{DISCUSSION OF RESEARCH RESULTS}

In order to achieve the forecast values of the indicators representing the economic potential of the industrial sector of Surkhandarya region, it is necessary to take into account: increase the volume of investments in the industrial sector, as well as ensure its efficient use; increase labor productivity by equipping labor resources with modern technologies and improving skills; development and implementation of prospects for further development of industrial production on the basis of scientific analysis.

In our opinion, natural resources, means of production, labor resources and technical potential, as well as the geographical location of the region are also important in the indicators of economic potential of the region's industry, and their interdependence can be expressed as follows (Figure 4).

\footnotetext{
${ }^{15}$ Author's calculations.
} 


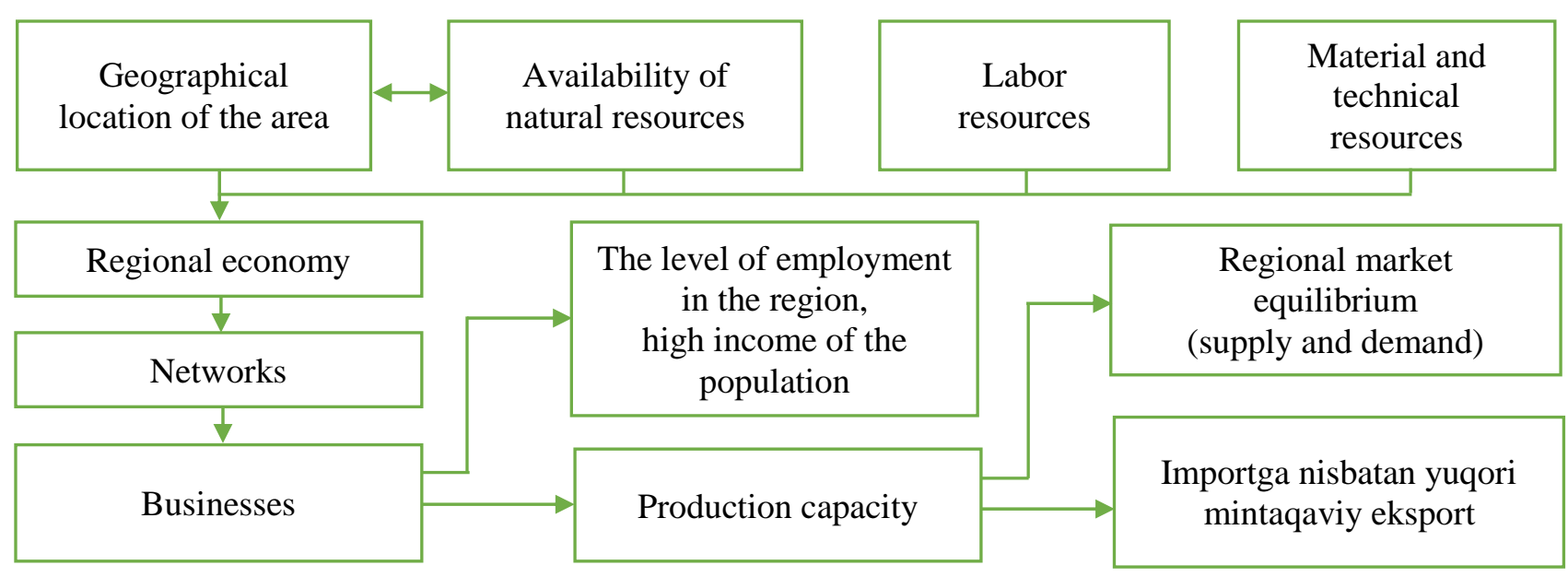

\section{Figure 4. The structure of the economic} potential of regional industry ${ }^{16}$

\section{CONCLUSIONS}

In general, the concept of economic potential includes components of the various historical stages of the activity of the productive forces, among which the potential of human resources and social production sectors have begun to be closely considered.

Today, there is a great need for qualified personnel for the effective operation of industrial production. It is known from world experience that the basis for achieving economic development is scientific and technological development, the development of which depends directly on qualified specialists and investment.

Therefore, in the development of strategies for the effective use of the economic potential of the industry of Surkhandarya region and its further development, it is expedient to take into account the following:

1. Scientific analysis of the factors that negatively affect the sustainable development of the regional economy and the use of research in this area and strengthening the mechanism of their full support;

2. Development of science and technology to increase the efficiency of factors of production and achieve the production of globally competitive products;

3. Creating favorable conditions for the establishment of new production facilities, financial assistance and removal of unnecessary bureaucratic barriers;

4. Improving the system of attention to human capital and improving its quality, strengthening the practice of proper distribution of income and socio-financial support of specialists;

5. Rational and efficient use of natural resources, optimal allocation of productive forces, technological modernization and diversification of direct production, direct investment in personnel development and the transition to an innovative production corridor;

6. In order to increase the investment attractiveness of regional industry: improve the logistics infrastructure in the regions, increase the material interest of

\footnotetext{
${ }^{16}$ Created by the author.
} 
foreign investors and improve the mechanism of institutional support for their activities;

7. Satisfying the need for qualified personnel through the fair organization of interaction between the real sectors of the economy and educational institutions and the application of international innovative approaches in this regard, etc.

High economic potential and scientific and technological progress can be achieved by assessing the impact of factors in the development of regional industry, increasing resource efficiency based on analysis and stimulating innovation and the introduction of research and development.

\section{REFERENCES}

1. Vahobov A.V., Khajibakiev Sh.X., Muminov N.G. (2010). Foreign investment. Study guide. - T.: "Finance”. 26 p.

2. Batirova N. (2019). Features of industrial development of the tashkent region // The Light of Islam. Iss. 4, 2 p.

3. Djumanova R.F. (2012). Modeling and forecasting of socio-economic processes: Training manual. -T.: UzMU. 15 p.

4. Domar E. (1946). Capital Expansion, Rate of Growth and Employment // Econometrica. №2, 137-147 p.

5. Eremeeva L.N., Plisetskiy E.L. (2013). Regional policy in modern Russia: features of formation and implementation // Economy. Taxes. Right. No.6, 8 p.

6. Glushko V.O., Zornikova N.V., Shamardina O.V. (2017). Statistical analysis of industrial production in Russia / Scientific community of students: Interdisciplinary research: collection of articles. Art. by material. XXVIII int. scientific-practical conf. No.17 (28). 90 p.
7. Grebenkin I.V., Botkin I.O. (2017). Assessment of regional clusters in mechanical engineering // Economics and Law. No. 4. 14-22 p.

8. Harrod R.F. (1939). An Essay in Dynamic Theory // Economic Journal. №49, 14-33 p.

9. Korobeinikov O.P., Khavin D.V., Nozdrin V.V. (2003). Enterprise economy. Tutorial. Nizhny Novgorod, - “ORKS”. 47 p.

10. Lavopa A., Szirmai A. (2012). "Industrialization, employment and poverty", MERIT Working Papers 2012-081, United Nations University - Maastricht Economic and Social Research Institute on Innovation and Technology (MERIT).

11. Mahmudov M.F. (2019). Assessment of industrial production potential of Uzbekistan // Economy and innovative technologies. №1, 2 p.

12. Mahmudov N., Butabaev M., Khaitqulov A. (2018). Ways of effective use of the potential of the processing industry of the region / Collection of scientific articles of the Republican scientific-practical conference "Sustainable development of the economy of Uzbekistan: factors, results and prospects", T.: TSUE, $422 \mathrm{p}$.

13. Ortiqov A. (2009). Industrial economics. Textbook. T.: TSUE, $236 \mathrm{p}$.

14. Salimov B.B. (2018). Comparative analysis of canoe production by regions and priorities for its development // Economy and innovative technologies. №3, $11 \mathrm{p}$.

15. Topoleva T.N. (2018). Formation of an innovative model for the development of industrial enterprises // Bulletin of PNRPU. Socio-economic sciences. No. 4. - 221 p. 
Doi: https://doi.org/10.37547/tajmei/Volumeo2Issue11-01

16. Shodiev T.Sh., Xakimov T.X. et al. (2007).

Econometrics. Study guide. -T.: TSUE. 58 p.

17. Resolution of the President of the Republic of Uzbekistan dated March 29, 2018 No PP3635 "On measures to establish small industrial zones in Surkhandarya region", https://lex.uz/docs/3604679 